\title{
OPTIMASI METODE PENENTUAN KADAR LOGAM TEMBAGA DAN TIMBAL DALAM GULA PASIR SECARA SPEKTROFOTOMETRI SERAPAN ATOM DENGAN DESTRUKSI MICROWAVE DIGESTION
}

\author{
Diana Candra Dewi, Begum Fauziyah, Arief Suryadinata, \\ Dewi Annisa, dan Nurul Afifah.
}

\author{
Jurusan Kimia, Fakultas Sains dan Teknologi UIN Maulana Malik Ibrahim Malang
}

\begin{abstract}
Copper $(\mathrm{Cu})$ and Lead $(\mathrm{Pb})$ were one of the trace element found in sugar that comes from the manufacturing process such as corrosion processes in the circuit of the equipment. This study aims to find the optimum temperature and time of microwave digest, to find the analytical performance of the standard curve and standard addition curve and test compatibility the results.

This research include determining optimum temperature and time of microwave destruction for sugar with temperature variation of $160,180,200{ }^{\circ} \mathrm{C}$, time variation $10,15,20$ and 30 minutes and storage time 1 until 5 days. Analytical performance of the standard curve of $\mathrm{Cu}$ and $\mathrm{Pb}$ includes linearity, LOD, LOQ, sensitivity, accuracy, precision, continued by determination of the analytical performance using the standard addition curve with optimum temperature and time.

The study obtained that the optimum temperature and time of microwave digest for $\mathrm{Cu}$ analysis is $200{ }^{0} \mathrm{C}$ and 15 minutes with maximum storage time 3 days, while optimum temperature and time of microwave digest for $\mathrm{Pb}$ analysis $180{ }^{\circ} \mathrm{C}$ and 10 minutes with maximum storage time only one day. Analytical performance of the standard curve of $\mathrm{Cu}$ includes $\mathrm{r}^{2}=0.9993$; LOD $0.0011 \mathrm{ppm}$; LOQ $0.0036 \mathrm{ppm}$; sensitivity 0.2 ; average accuracy of $99,96 \%$, and precision of $9.46 \%$. Analytical performance of the standard addition curve for copper $(\mathrm{Cu})$ includes $\mathrm{r}^{2}=0.9999$; LOD $0.0012 \mathrm{ppm}$; LOQ $0.004 \mathrm{ppm}$; sensitivity of 0.1729 , an average accuracy of 100,07 and precision of $5.38 \%$. Analytical performance of the standard curve of $\mathrm{Pb}$ includes $\mathrm{r}^{2}=0.9999$, LOD $0.0019 \mathrm{ppm}$, LOQ $0.0066 \mathrm{ppm}$, the sensitivity of 0.1069 , the average accuracy of $99.56 \%, 2.32 \%$ and the precision of the analytical performance of the standard curve addition includes standard $\mathrm{r}^{2}=0.9999$, LOD 0.0018 ppm, LOQ $0.0060 \mathrm{ppm}$, the sensitivity of 0.1090 , the average accuracy of $100.01 \%$, and precision of $1.94 \%$.
\end{abstract}

Key words : Copper $(\mathrm{Cu})$, Lead $(\mathrm{Pb})$, Sugar, Microwave Digest, Atomic Absorption Spectroscopy.

\section{ABSTRAK}

Tembaga $(\mathrm{Cu})$ dan Timbal $(\mathrm{Pb})$ adalah bahan ikutan yang ditemukan dalam gula pasir. Penelitian ini bertujuan mengetahui performa analitik kurva standar dengan penentuan suhu dan waktu terbaik destruksi menggunakan microwave digestion, serta performa analitik kurva adisi standar menggunakan suhu dan waktu terbaik destruksi.

Penelitian ini meliputi penentuan performa analitik untuk kurva standar yaitu linearitas, batas deteksi dan batas kuantitasi, sensitivitas, akurasi serta presisi untuk larutan standar $\mathrm{Cu}$ dan $\mathrm{Pb}$, kemudian dilakukan pendestruksian sampel gula pasir dengan destruksi basah menggunakan microwave digestion dengan variasi suhu 160, 180 dan $200{ }^{\circ} \mathrm{C}$ dan variasi waktu 10, 15, 20 dan 30 menit dan waktu penyimpanan 1 sampai 5 hari. Penentuan performa analitik juga ditentukan pada kurva adisi standar untuk larutan $\mathrm{Cu}$ dan $\mathrm{Pb}$ yang telah ditambahkan sampel hasil destruksi.

Hasil penelitian menunjukkan bahwa : Suhu dan waktu terbaik destruksi gula pasir menggunakan microwave digestion untuk analisis $\mathrm{Cu}$ yaitu suhu $200{ }^{\circ} \mathrm{C}$ dan waktu 15 menit serta waktu penyimpanan sampai 3 hari. Suhu dan waktu terbaik microwave digestion untuk menganalisa logam timbal $(\mathrm{Pb})$ adalah $180{ }^{\circ} \mathrm{C}$ dan 10 menit serta waktu penyimpanan hanya sampai 1 hari. Performa analitik untuk kurva standar tembaga $(\mathrm{Cu})$ meliputi $\mathrm{r}^{2}=0,9993$; LOD (Limit of Detection) 0,0011 ppm dan LOQ (Limit of Quantitation) 0,0036 ppm; sensitivitas 0,2; rata-rata akurasi sebesar 99.96\%; serta presisi 9,46\%, sedangkan performa analitik untuk kurva adisi standar tembaga $(\mathrm{Cu})$ meliputi $\mathrm{r}^{2}=0,9999$; LOD 0,0012 ppm dan LOQ 0,004 ppm; sensitivitas 0,1729, rata-rata akurasi sebesar $100,07 \%$ serta presisi 5,38\%. Performasi analitik untuk kurva standar timbal $(\mathrm{Pb})$ meliputi $\mathrm{r}^{2}=0,9999$; LOD 0,0019 ppm, LOQ 0,0066 ppm; sensitivitas 0,1069 ppm ; rata-rata akurasi sebesar $99,56 \%$ serta presisi $2,32 \%$. Performasi analitik kurva adisi standar timbal $(\mathrm{Pb})$ meliputi $\mathrm{r}^{2}=0,9999$; LOD 0,0018 ppm, LOQ 0,0060 ppm; sensitivitas 0,1090 ppm; rata-rata akurasi sebesar 100,01\% serta presisi 1,94\%.

Kata kunci : Tembaga $(\mathrm{Cu})$, Timbal $(\mathrm{Pb})$, gula pasir, Microwave Digestion, Spektroskopi Serapan Atom 


\section{PENDAHULUAN}

Gula merupakan disakarida yang menjadi sumber energi dan banyak diperdagangkan dalam bentuk kristal sukrosa padat. Gula digunakan untuk mengubah rasa menjadi manis dan warna fisik makanan (karamelisasi) atau minuman. Gula sebagai sukrosa diperoleh dari nira tebu, bit, atau aren (Santoso, 2008). Proses pembuatan gula pasir dari batang tebu melalui beberapa proses, diantaranya adalah penggilingan tebu (pemerahan nira), klarifikasi, penguapan, kristalisasi, pemurnian raw sugar, dan dekolorisasi.

Gula pasir dapat berpotensi besar tercemar oleh logam tembaga. Hal tersebut disebabkan tuanya mesin produksi yang dikarenakan hampir 90\% mesin pabrikpabrik gula yang ada di Indonesia rata-rata dibuat pada tahun 1800-an (Carebet, 1997). Selain itu karena dalam proses produksi menggunakan pemanasan dengan suhu tinggi yang dapat memperbesar potensi cemaran tembaga dalam bentuk ion bebas larut saat proses produksi.

Logam tembaga $(\mathrm{Cu})$ berperan sebagai metal cofactor dalam sistem metabolisme organisme hidup (Hutagalung dan Sutomo, 1999). Kadar unsur tembaga di dalam tubuh tidak boleh kurang ataupun lebih. Logam tembaga dalam jumlah berlebih dapat bersifat racun bagi organisme. Keracunan tembaga pada manusia dapat terjadi karena adanya tembaga dalam bahan pangan yang dikonsumsi. Misalnya, bahan pangan yang dikemas menjadi makanan kaleng, suplemen yang mengandung tembaga maupun gula pasir (Setiady, 2008)

Kontaminasi logam timbal dalam gula pasir dapat disebabkan dari air yang digunakan dan penambahan larutan form $\mathrm{A}$ dan form B pada proses penjernihan (Suksmaji, 2001). Maksimal logam timbal $(\mathrm{Pb})$ didalam tubuh $10 \mu \mathrm{g} / \mathrm{L}$. Menurut SNI, maksimal logam timbal dalam makanan adalah 2 ppm, sedangkan menurut (ICUMSA) standar maksimal logam timbal sebesar 0,5. Adapun syarat mutu cemaran logam tembaga $(\mathrm{Cu})$ menurut Standar Nasional Indonesia (SNI) untuk gula kristal putih pada SNI 3140.3:2010 untuk batas maksimum yaitu sebesar 2 ppm. Sedangkan menurut International Commission for Uniform Methods of Sugar Analysis atau ICUMSA (2011), syarat mutu cemaran logam tembaga $(\mathrm{Cu})$ untuk gula kristal putih untuk batas maksimum yaitu sebesar $1 \mathrm{ppm}$.

Analisis logam menggunakan SSA harus memenuhi syarat yaitu logam yang akan dianalisis harus dalam keadaan bebas dan bukan dalam bentuk senyawa bersama molekul lain. Untuk memecah ikatan kovalen antara sukrosa dengan logam harus dilakukan pendestruksian yang tepat yang mampu melarutkan larutan (sukrosa), memutuskan ikatan logam dengan sukrosa dan mampu mempertahankan kestabilan logam salah satunya adalah dengan microwave (Berghoff, 2000).

\section{METODE PENELITIAN Alat dan Bahan Penelitian}

Alat yang digunakan pada penelitian ini antara lain seperangkat instrument Spektroskopi Serapan Atom merk Varian spectra AA 240, microwave digestion merk Mars Xpress, timbangan analitik, peralatan alat gelas laboratorium, botol semprot, botol plastik sampel, vessel, rak vessel, oven, lemari asam, desikator dan pipet tetes.

Bahan yang digunakan pada penelitian ini adalah gula pasir, akuades, akuabidest, larutan standar $\mathrm{Cu} 1000$ ppm merk Merck, larutan standar Pb 1000 ppm merk E-Merck dan Asam Nitrat pekat $\left(\mathrm{HNO}_{3}\right)$.

\section{Pembuatan Kurva Standar Cu}

Dibuat sederetan larutan standar $\mathrm{Cu}$ $0,00 \mathrm{mg} / \mathrm{L} ; 0,02 \mathrm{mg} / \mathrm{L} ; 0,04 \mathrm{mg} / \mathrm{L} ; 0,06$ $\mathrm{mg} / \mathrm{L} ; 0,08 \mathrm{mg} / \mathrm{L}$ dan $0,1 \mathrm{mg} / \mathrm{L}$ dengan pengencer $\mathrm{HNO}_{3}$ 0,5M ke dalam labu ukur $50 \mathrm{~mL}$ kemudian diencerkan sampai batas (ICUMSA, 2011). Sederetan larutan standar $\mathrm{Cu}$ dianalisis dengan Spektrofotometer Serapan Atom (SSA) merk Varian spectra 
AA 240 pada kondisi optimum sehingga diperoleh data absorbansi masing-masing (Rohman, 2007). Setelah didapatkan kurva standar maka dilakukan perhitungan terhadap performa analitik kurva standar yang meliputi linearitas, batas deteksi dan batas kuantitasi, sensitivitas, akurasi serta presisi.

\section{Pembuatan Kurva Standar Pb}

Larutan $\mathrm{Pb} 1000$ ppm diencerkan menjadi $10 \mathrm{ppm}$ dengan memindahkan 0,5 $\mathrm{mL}$ ke dalam labu ukur $50 \mathrm{~mL}$ kemudian diencerkan sampai tanda batas. Larutan $\mathrm{Pb}$ $0,2 \mathrm{mg} / \mathrm{L}$ dibuat dengan cara yang sama, namun larutan yang dipindahkan $1 \mathrm{~mL}$ larutan baku $10 \mathrm{mg} / \mathrm{L}$. Larutan standar $\mathrm{Pb}$ 0,02 ppm; 0,04 ppm; 0,06 ppm; 0,08 ppm; $0,1 \mathrm{ppm}$ dibuat dengan cara memindahkan $5 \mathrm{~mL} ; 10 \mathrm{~mL} ; 15 \mathrm{~mL} ; 20 \mathrm{~mL} ; 25 \mathrm{~mL}$ larutan baku $2 \mathrm{mg} / \mathrm{L}$ kedalam labu ukur 100 $\mathrm{mL}$ kemudian diencerkan sampai tanda batas.

\section{Penentuan Suhu dan Waktu Terbaik Destruksi Basah dengan Microwave Digestion}

Ditimbang sampel gula sebanyak 0.4 gram. Selanjutnya sampel gula yang akan didestruksi, masing-masing dimasukkan ke dalam 6 buah vessel. Ditambahkan $\mathrm{HNO}_{3}$ pekat sebanyak $10 \mathrm{ml}$ pada tiap vessel. Ditutup vessel dan diletakkan vessel di dalam rak. Selanjutnya dimasukkan rak vessel ke dalam microwave digestion dan ditutup pintu. Kemudian di setting suhu dan waktunya yaitu $160{ }^{\circ} \mathrm{C}, 180{ }^{\circ} \mathrm{C}$ dan $200{ }^{\circ} \mathrm{C}$ dan variasi waktu 10, 15, 20 dan 30 menit serta waktu penyimpanan 1 sampai 5 hari. Selanjutnya dimasukkan larutan ke labu takar $50 \mathrm{ml}$ dan ditanda bataskan dengan $\mathrm{HNO}_{3}$ 0,5 $\mathrm{M}$ dan dihomogenkan (CEM, 2010). Sampel ditentukan kadarnya menggunakan grafik kurva standar dengan SSA.

\section{Pembuatan Kurva Adisi Standar Cu dan Pb Menggunakan Waktu dan Suhu Terbaik}

Dibuat sederetan larutan standar $\mathrm{Cu}$ 0,00 mg/L; 0,02 mg/L;0,04 mg/L;0,06 $\mathrm{mg} / \mathrm{L} ; 0,08 \mathrm{mg} / \mathrm{L}$ dan $0,1 \mathrm{mg} / \mathrm{L}$ dibuat dengan cara memindahkan $0 \mathrm{~mL} ; 5 \mathrm{~mL} ; 10$ $\mathrm{mL} ; 15 \mathrm{~mL} ; 20 \mathrm{~mL}$ dan $25 \mathrm{~mL}$ larutan baku $0,2 \mathrm{mg} / \mathrm{L}$ ke dalam labu ukur $50 \mathrm{~mL}$ yang telah berisi $5 \mathrm{ml}$ sampel hasil destruksi suhu dan waktu terbaik kemudian diencerkan dengan $\mathrm{HNO}_{3}$ 0,5M sampai batas dan dianalisis dengan Spektrofotometer Serapan Atom (SSA) merk Varian spectra AA 240 pada kondisi optimum sehingga diperoleh data absorbansi masing-masing. Diulang dengan larutan standar $\mathrm{Pb}$ (Rohman, 2007).

\section{HASIL DAN PEMBAHASAN}

Penentuan Suhu dan Waktu Terbaik Destruksi Basah dengan Microwave Digestion untuk Analisis Cu pada Gula pasir

Penentuan suhu dan waktu terbaik destruksi basah menggunakan microwave digestion ditinjau dari kadar logam baik tembaga $(\mathrm{Cu})$ atau timbal $(\mathrm{Pb})$ yang terbaca paling tinggi. Untuk memecah ikatan kovalen antara sukrosa dengan logam harus dilakukan pendestruksian yang tepat yang mampu melarutkan larutan (sukrosa), memutuskan ikatan logam dengan sukrosa dan mampu mempertahankan kestabilan logam. Oleh karena itu, dibutuhkan suhu dan waktu terbaik destruksi dalam memecah ikatan antara senyawa organik dengan logam.

Penentuan suhu optimum untuk analisis logam dilakukan destruksi dengan variasi suhu $160{ }^{\circ} \mathrm{C}, 180{ }^{\circ} \mathrm{C}$ dan $200{ }^{\circ} \mathrm{C}$ dengan waktu sebesar 15 menit. Adapun hasil analisis menggunakan spektroskopi serapan atom adalah logam tembaga Kadar tembaga yang terbaca terus meningkat seiring dengan bertambahnya suhu destruksi. Data perolehan logam tembaga (Cu) menggunakan variasi suhu $160{ }^{\circ} \mathrm{C}$, $180{ }^{\circ} \mathrm{C}$ dan $200{ }^{\circ} \mathrm{C}$ dengan waktu sebesar 15 menit disajikan pada grafik hubungan antara kadar logam tembaga yang terbaca 
dengan variasi suhu destruksi sebagai berikut:

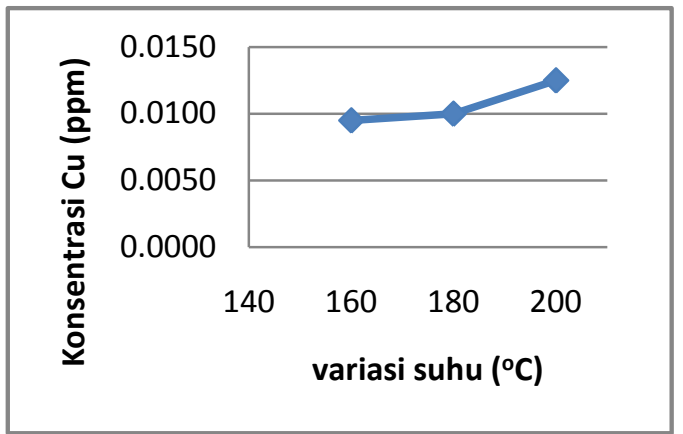

Gambar 1. Grafik hubungan variasi suhu destruksi dengan konsentrasi logam $\mathrm{Cu}$

Pada data yang diperoleh tersebut telah diketahui bahwa nilai rerata absorbansi paling tinggi ditunjukkan pada suhu $200{ }^{\circ} \mathrm{C}$ sebesar 0,0031 dan konsentrasi yang diperoleh sebesar 0,0125 ppm. Sehingga diketahui bahwa suhu terbaik untuk destruksi gula pasir menggunakan microwave digestion sebesar $200{ }^{\circ} \mathrm{C}$. Kemudian setelah diperoleh suhu terbaik destruksi menggunakan microwave digestion maka dilanjutkan dengan destruksi untuk mengetahui waktu terbaik destruksi menggunakan microwave digestion. Dilakukan destruksi pada suhu $200{ }^{\circ} \mathrm{C}$ dengan variasi waktu sebesar 15,20 dan 25 menit.

Adapun data perolehan logam tembaga $(\mathrm{Cu})$ menggunakan suhu $200{ }^{\circ} \mathrm{C}$ dengan variasi waktu sebesar 15, 20 dan 25 menit. disajikan pada grafik hubungan antara kadar logam tembaga yang terbaca dengan variasi suhu destruksi sebagai berikut:

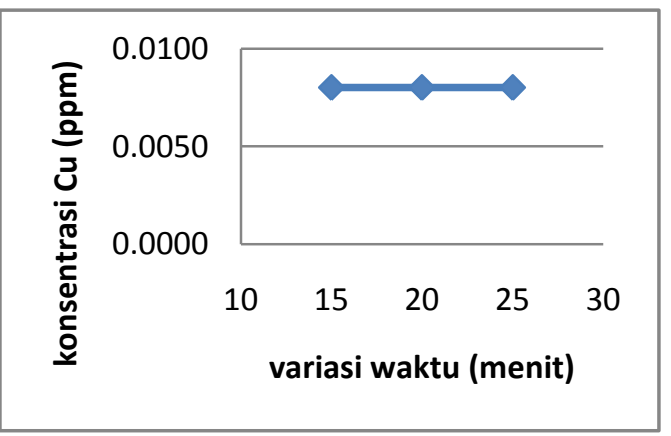

Gambar 2. Grafik hubungan variasi waktu destruksi dengan konsentrasi $\operatorname{logam} \mathrm{Cu}$
Dari data yang diperoleh dapat diketahui bahwa waktu terbaik untuk destruksi gula pasir menggunakan microwave digestion sebesar 15 menit. Waktu destruksi ini berhubungan dengan banyaknya sampel yang didestruksi. Semakin banyak sampel yang akan didestruksi maka semakin lama pula proses destruksi tersebut berlangsung. Sehingga dapat diketahui bahwa waktu terbaik untuk mendestruksi 0,4 gram sampel gula pasir dibutuhkan waktu selama 15 menit. Dari destruksi yang telah dilakukan tersebut diketahui bahwa suhu terbaik destruksi menggunakan microwave digestion sebesar $200{ }^{\circ} \mathrm{C}$ dan waktu terbaik destruksi menggunakan microwave digestion selama 15 menit. Selanjutnya ditentukan kestabilan kadar logam tembaga $(\mathrm{Cu})$ pada suhu dan waktu terbaik destruksi menggunakan microwave digestion dengan berbagai waktu penyimpanan seperti gambar berikut:

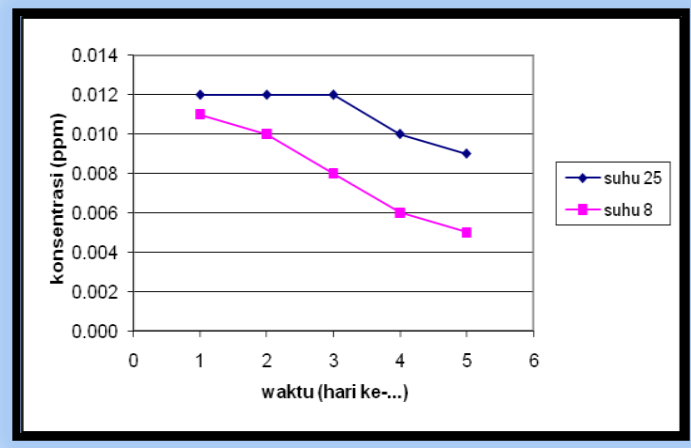

Gambar 3 Grafik hubungan variasi waktu penyimpanan dengan konsentrasi logam $(\mathrm{Cu})$

Dari grafik diatas diketahui bahwa kestabilan logam tembaga $(\mathrm{Cu})$ sangat baik pada suhu $25^{\circ} \mathrm{C}$ jika dibandingkan dengan suhu $8^{\circ} \mathrm{C}$ yang mengalami penurunan konsentrasi yang lebih tajam. Penurunan kadar tembaga $(\mathrm{Cu})$ yang terjadi tersebut disebabkan adanya molekul sukrosa yang mengikat kembali logam tembaga tersebut karena pada suhu ruang $\left(25{ }^{\circ} \mathrm{C}\right)$ tidak dapat mengontrol suhu agar tetap berada pada 25 ${ }^{\circ} \mathrm{C}$ sehingga jika ada penurunan suhu beberapa derajat maka juga akan 
mempengaruhi kestabilan dari larutan sampel tersebut.

\section{Penentuan Suhu dan Waktu Terbaik Destruksi Basah dengan Microwave Digestion untuk Analisis Pb pada Gula pasir}

Penentuan suhu optimum metode destruksi microwave dilihat dari nilai konsentrasi tertinggi pada setiap variasi suhu. Adapun hasil pengukuran menggunakan SSA tersaji pada gambar dibawah ini :

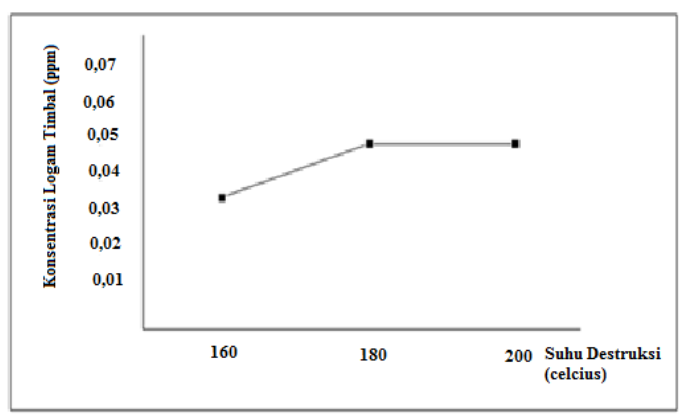

Gambar 4 Grafik hubungan variasi suhu dengan konsentrasi logam $(\mathrm{Pb})$

Pada gambar dapat dilihat bahwa, terjadi kenaikan konsentrasi logam timbal (Pb) pada suhu $160{ }^{0} \mathrm{C}$ dari konsentrasi sebesar 0,03 ppm menjadi $0,05 \mathrm{ppm}$ pada suhu $180{ }^{\circ} \mathrm{C}$ dan konstan pada suhu $200{ }^{\circ} \mathrm{C}$, sehingga dapat disimpulkan bahwa suhu optimum dari proses destruksi gula sebesar $180{ }^{\circ} \mathrm{C}$.

Pengamatan waktu optimum metode destruksi microwave dilakukan pada waktu 10 menit, 15 menit, dan 30 menit. Waktu optimum dapat dilihat dari nilai konsentrasi tertinggi. Adapun hasil pengukuran menggunakan SSA tersaji pada gambar 5.

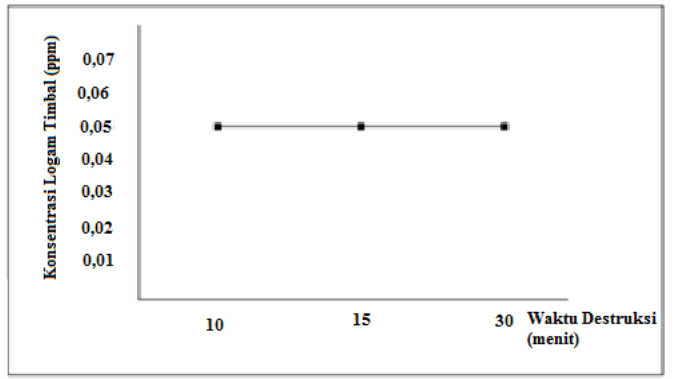

Gambar 5 Grafik hubungan variasi waktu destruksi dengan konsentrasi logam $(\mathrm{Pb})$
Pada gambar diatas dapat dilihat bahwa, konsentrasi logam timbal berada pada keadaan konstan sebesar 0,05 ppm. Dengan demikian, dapat diketahui bahwa, waktu memiliki pengaruh yang kecil dalam proses destruksi logam timbal pada sukrosa.

\section{Grafik kestabilan logam timbal dengan menggunakan suhu $180^{\circ} \mathrm{C}$}

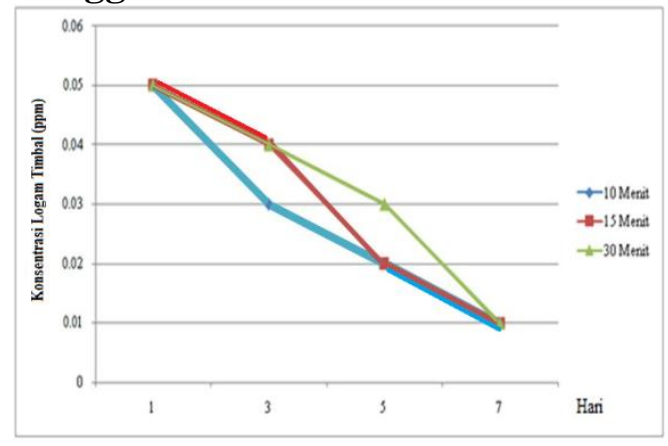

Gambar 6 Grafik hubungan variasi waktu penyimpanan dengan konsentrasi $\operatorname{logam} \mathrm{Cu}$

Penurunan kadar timbal $(\mathrm{Pb})$ yang terjadi tersebut disebabkan adanya molekul sukrosa yang mengikat kembali logam timbal tersebut karena pada suhu ruang (25 ${ }^{\circ} \mathrm{C}$ ) tidak dapat mengontrol suhu agar tetap berada pada $25{ }^{\circ} \mathrm{C}$ sehingga jika ada penurunan suhu beberapa derajat maka juga akan mempengaruhi kestabilan dari larutan sampel tersebut.

Penentuan Performa analitik analisis kadar tembaga (Cu) menggunakan kurva standar dan kurva adisi standar

Dalam penentuan suhu dan waktu terbaik telah didapatkan hasil bahwa suhu destruksi $200{ }^{\circ} \mathrm{C}$ dengan waktu destruksi 15 menit. Pada penelitian ini larutan sampel yang ditambahkan adalah $5 \mathrm{~mL}$ dan diencerkan menjadi $50 \mathrm{~mL}$. Adapun hasil pengukuran kadar logam tembaga $(\mathrm{Cu})$ menggunakan kurva adisi standar adalah 0,081 ppm dan pada ulangan kedua sebesar 0,075 ppm.Untuk perbandingan performa analitik antara kurva standar dan adisi standar tersaji pada Tabel 1. 
Tabel 1. Perbandingan performa analitik antara dua metode

\begin{tabular}{|c|c|c|}
\hline Parameter & $\begin{array}{l}\text { Kurva } \\
\text { Standar }\end{array}$ & $\begin{array}{c}\text { Kurva } \\
\text { Adisi } \\
\text { Standar }\end{array}$ \\
\hline Linearitas & $\begin{array}{c}0,9993 \\
\mathrm{ppm}\end{array}$ & $\begin{array}{c}0,9999 \\
\mathrm{ppm}\end{array}$ \\
\hline $\begin{array}{l}\text { Batas Deteksi } \\
\text { (LOD) } \\
\text { Batas Kuantitasi } \\
\text { (LOQ) }\end{array}$ & $\begin{array}{c}0,0011 \\
\text { ppm } \\
0,0036 \\
\text { ppm }\end{array}$ & $\begin{array}{c}0,0012 \\
\text { ppm } \\
0,0040 \\
\text { ppm }\end{array}$ \\
\hline Sensitivitas & 0,2 & 0,1729 \\
\hline $\begin{array}{l}\text { Rata-rata } \\
\text { Akurasi }\end{array}$ & $99.96 \%$ & $100.07 \%$ \\
\hline Presisi & $9,46 \%$ & $5,38 \%$ \\
\hline
\end{tabular}

Parameter yang pertama dibandingkan adalah linearitas. Untuk harga $\mathrm{r}^{2}$ pada kedua kurva adalah sama sensitifnya dimana harga $\mathrm{r}^{2}$ untuk kurva standar adalah 0,9993 dan kurva adisi standar adalah 0,9999. Semakin mendekati nilai 1 maka linearitas sebuah kurva akan semakin sensitif (Skoog, 1985). Parameter kedua yang dibandingkan adalah nilai LOD dan LOQ. Dari Tabel diatas dapat diketahui bahwa nilai LOD dan LOQ dari kurva adisi standar tembaga $(\mathrm{Cu})$ lebih besar daripada kurva standar tembaga $(\mathrm{Cu})$ sehingga kurva kalibrasi dapat mendeteksi analit sampai batas terkecil tersebut. Adapun nilai dari LOD dan LOQ dari kurva standar dan adisi standar berturut-turut adalah 0,$0011 ; 0,0036$ dan 0,0012;0,0040.

Parameter yang ketiga adalah sensitivitas. Dari data dapat diketahui nilai 0,1729 untuk kurva adisi stándar dan 0,2 untuk kurva stándar, hal ini menunjukan bahwa nilai sensitivitas kurva stándar lebih tinggi daripada kurva adisi standar sehingga kurva standar lebih sensitif daripada kurva adisi standar. Parameter selanjutnya adalah akurasi. Dari Tabel dapat diketahui bahwa dalam kurva stándar dan kurva adisi standar seluruh data yang diterima secara statistik dikarenakan semua data masih memenuhi range tersebut yakni berkisar 98\% - 102\%.
Sehingga dapat dikatakan kurva standar dan kurva adisi stándar memenuhi persyaratan akurasi. Parameter yang terakhir adalah presisi. Hasil analisa menunjukan presisi untuk kurva stándar dan adisi stándar berturut-turut adalah $9,46 \%$ dan $5,38 \%$. Presisi kedua metode ini masih memenuhi persyaratan presisi yakni dibawah $16 \%$.

Kurva adisi standar lebih sensitif dibandingkan dengan kurva standar dikarenakan pada metode adisi standar terjadi koreksi antara sampel dengan matriks. Namun metode adisi standar membutuhkan waktu pengerjaan yang lama, keadaan ini disebabkan ketika akan menganalisa sebuah sampel maka harus membuat kurva terlebih dahulu. Berbeda lagi dengan kurva standar yang dapat dilakukan pembacaan ulang untuk sampel selanjutnya (recall) terhadap kurva terdahulu sehingga waktu yang digunakan lebih efektif dan efesien. Dimana ketika akan banyak sampel yang dianalisa dengan waktu pengerjaan yang membutuhkan waktu relatif singkat maka kurva standar ini bisa digunakan sebagai alternatif metode (Andarwulan, 2011).

Perbandingan hasil pengukuran antara kurva standar dan kurva adisi standar untuk pengukuran kadar logam tembaga $(\mathrm{Cu})$ dalam gula pasir kemasan tersaji sebagai berikut:

Tabel 2. Perbandingan hasil pengukuran kadar logam tembaga $(\mathrm{Cu})$ dalam gula pasir kemasan

\begin{tabular}{|c|c|}
\hline Metode & Konsentrasi \\
\hline $\begin{array}{c}\text { Kurva adisi } \\
\text { standar }\end{array}$ & 0,9375 \\
\hline $\begin{array}{c}\text { Kurva } \\
\text { Standar }\end{array}$ & 0,9750 \\
\hline
\end{tabular}

Penentuan Performa analitik analisis kadar timbal ( $\mathrm{Pb})$ menggunakan kurva standar dan kurva adisi standar

Dalam penentuan suhu dan waktu terbaik telah didapatkan hasil bahwa suhu destruksi $180{ }^{\circ} \mathrm{C}$ dengan waktu destruksi 15 
menit. Pada penelitian ini larutan sampel yang ditambahkan adalah $5 \mathrm{~mL}$ dan diencerkan menjadi $50 \mathrm{~mL}$. Adapun performa analitik untuk metode destruksi microwave yang diukur dari kurva standar $\mathrm{Pb}$, antara lain:

Tabel 3 Perbandingan performa analitik antara dua metode

\begin{tabular}{|c|c|c|}
\hline $\begin{array}{c}\text { Parameter/ } \\
\text { Metode }\end{array}$ & $\begin{array}{c}\text { Kurva } \\
\text { Standar }\end{array}$ & $\begin{array}{c}\text { Kurva } \\
\text { Adisi } \\
\text { Standar }\end{array}$ \\
\hline Linearitas & 0,9999 & 0,9999 \\
\hline (LOD)/ppm & 0,0019 & 0,0018 \\
(LOQ)/ppm & 0,0066 & 0,0060 \\
\hline Sensitivitas & 0,1069 & 0,1090 \\
\hline Rata-rata & $99,56 \%$ & $100,01 \%$ \\
Akurasi & & \\
\hline Presisi & $2,32 \%$ & $1,94 \%$ \\
\hline
\end{tabular}

\section{Penentuan Konsentrasi Logam (Pb) dalam gula pasir}

Perbandingan hasil pengukuran antara kurva standar dan kurva adisi standar untuk pengukuran kadar logam tembaga $(\mathrm{Pb})$ dalam gula pasir kemasan tersaji sebagai berikut:

Tabel 4. Perbandingan hasil pengukuran kadar logam tembaga $(\mathrm{Pb})$ dalam gula pasir kemasan

\begin{tabular}{|c|c|}
\hline Metode & Konsentrasi \\
\hline Kurva adisi standar & $0,37 \mathrm{ppm}$ \\
\hline Kurva Standar & $0,32 \mathrm{ppm}$ \\
\hline
\end{tabular}

Dalam penelitian ini digunakan destruksi basah karena pada umumnya destruksi basah dapat dipakai untuk menentukan unsur-unsur dengan konsentrasi yang rendah. Dalam analisis gula pasir kemasan ini menggunakan metode destruksi basah dengan instrumen microwave digestion dan zat pengoksidasi $\mathrm{HNO}_{3} \quad 65 \%$ yang berfungsi sebagai destruktor. Larutan ini dipakai untuk bahanbahan organik yang sulit dihancurkan.

Sukrosa adalah suatu disakarida heterogen tersusun dari unit D-glukosa dan D-fruktosa. Dilihat dari strukturnya, sukrosa mempunyai potensi yang cukup besar untuk terputus atom hidrogennya pada gugus $-\mathrm{OH}$ karena pemanasan. Mekanisme pemutusan yang terjadi antara gugus $-\mathrm{OH}$ yang terikat pada sukrosa dengan ion logam yang bermuatan positif (kation). $\mathrm{M}^{+}$dan $\mathrm{M}^{2+}$ adalah ion logam, $\mathrm{OH}$ adalah gugus hidroksil dan $\mathrm{Y}$ adalah matriks tempat gugus -OH terikat (sukrosa). Interaksi antara gugus $-\mathrm{OH}$ dengan ion logam juga memungkinkan melalui mekanisme pembentukan kompleks koordinasi karena atom oksigen $(\mathrm{O})$ pada gugus $-\mathrm{OH}$ mempunyai pasangan elektron bebas, sedangkan ion logam mempunyai orbital $d$ kosong. Pasangan elektron bebas tersebut akan menempati orbital kosong yang dimiliki ion logam, sehingga terbentuk senyawa atau ion kompleks. Sehingga berdasarkan teori tersebut ion dengan gugus hidroksil (-OH) melibatkan terbentuknya ikatan kovalen koordinasi, hal ini dimungkinkan karena atom oksigen $(\mathrm{O})$ pada gugus hidroksil (-OH) mempunyai pasangan elektron bebas sedangkan ion logam mempunyai orbital $d$ yang kosong. Pasangan elektron bebas tersebut akan menempati orbital kosong yang dimiliki oleh ion logam sehingga terbentuk suatu kompleks koordinasi. Pada pembentukan kompleks koordinasi, kation ion bertindak sebagai ion pusat dan sukrosa bertindak sebagai ligan.

\section{KESIMPULAN}

Dari penelitian dapat diambil kesimpulan sebagai berikut:

1. Suhu dan waktu terbaik destruksi gula pasir menggunakan microwave digestion yaitu untuk suhu terbaik sebesar $200{ }^{\circ} \mathrm{C}$ dan untuk waktu terbaik sebesar 15 menit. Suhu dan waktu optimum optimum oven microwave digest untuk menganalisa logam timbal $(\mathrm{Pb})$ adalah $180{ }^{\circ} \mathrm{C}$ dan 10 menit

2. Performa analitik untuk kurva standar tembaga $(\mathrm{Cu})$ meliputi $\mathrm{r}^{2}=0,9993$; LOD (Limit of Detection) 0,0011 ppm dan LOQ (Limit of Quantitation) 0,0036 ppm; sensitivitas 0,2; akurasi rerata sebesar 99.96\%; serta presisi 9,46\%, sedangkan performa analitik untuk 
kurva adisi standar tembaga $(\mathrm{Cu})$ meliputi $\mathrm{r}^{2}=0,9999$; LOD 0,0012 ppm dan LOQ 0,004 ppm; sensitivitas 0,1729, akurasi rerata sebesar $100,07 \%$ serta presisi 5,38\%. Performasi analitik untuk kurva standar timbal $(\mathrm{Pb})$ meliputi $\mathrm{r}^{2}=$ 0,9999; LOD 0,0019 ppm , LOQ 0,0066 ppm; sensitivitas 0,1069 ppm ; akurasi sebesar 99,56\%, serta presisi 2,32\%. Performasi analitik untuk kurva adisi standar timbal $(\mathrm{Pb})$ meliputi $\mathrm{r}^{2}=0,9999$; LOD 0,0018 ppm, LOQ 0,0060 ppm; sensitivitas 0,1090 ppm; akurasi sebesar $100,01 \%$, serta presisi $1,94 \%$.

\section{SARAN}

Penelitian selanjutnya dapat

dilakukan yaitu:

1. Variasi tekanan, daya, variasi jumlah oksidator yang digunakan dan variasi rentang variasi suhu dan waktu destruksi

2. Penelitian logam lain selain tembaga dan timbal pada gula pasir

3. Membandingkan dengan metode SNI maupun ICUMSA yang telah ada sehingga dapat diketahui metode yang lebih baik secara nyata.

\section{DAFTAR PUSTAKA}

Allen, Lori. B.,Siitonen, Paul.H, dan Thompson, Jr. 1997. Method for the Determination of Arsenic, Cadmium, Copper, Lead, and Tin in Sucrose, Corn Syrup and High-Fructose Corn Syrup by Inductively Coupled Plasma Atomic Emission Spectrometry. Journal Agriculture Food Chemistry, Vol. 45.

AOAC. 2002. Lead, Cadmium, Zinc, Copper, and Iron in Food: Atomic Absorption Spectrophotometry after Microwave Digestion. AOAC International
Berghof. 2000. Theory of Sample Preparation Using Acid Digestion, Pressure Digestion and Microwave Digestion (Microwave

Decomposition). Jerman: Zandel Holding Enterprise. http://www.berghof-instruments.de (diakses 5 Desember 2011)

Carebet . 1997. Penelitian Sirkulasi Imbibisi. Majalah Perusahaan Gula Vol XIII No. 2. Pasuruan : BP3G.

CEM. 2010. Manual Book: Application Note for Acid Digestion. CEM Coorporation

Hutagalung, P. H dan Sutomo. 1999. Kandungan $\mathrm{Cu}$ dan $\mathrm{Zn}$ dalam kerang hijau (Mytilus viridis Linn) dan karang darah (Anadara ceranosa Linn) dari Perairan Teluk Banten. Prosiding Seminar Tentang Oseanologi dari Ilmu Lingkungan Laut. Puslitbang Oseonologi LIPI: Jakarta

ICUMSA. 2011. New Method GS 9-9: Copper in Plantation White Sugar by Flame Atomic Absorption Spectroscopy. ICUMSA (International Commission for Uniform Method of Sugar Analysis)

Instruction Manual. Varian Spectra AA 240. Varian Spectra Atomic Absorption Spectrophotometer

Rohman, A. 2007. Kimia Farmasi Analisis. Yogyakarta: Pustaka Pelajar

Setiady, S.A. 1997. Penentuan Kandungan Tembaga dan Timbal dalam Susu Kental Manis dengan Spektrofotometri Serapan Atom [Skripsi Jurusan Kimia]. Fakultas MIPA : Universitas Islam Indonesia.

SNI 3140.3:2011. Gula Kristal Putih (Plantation White Sugar). SNI (Standar Nasional Indonesia)

Suksmaji, 2001. Proses Pembuatan Gula .Pasuruan:P3GI 